\title{
ASSESSMENT OF LIPID PROFILE OF EIGHT PROPOLIS SAMPLES FROM WESTERN ROMANIA
}

\author{
ALEXANDRA DUCA ${ }^{1}$ ERSILIA ALEXA ${ }^{2}$, CRISTINA ADRIANA DEHELEAN ${ }^{3}$, CODRUTA $^{2}$ \\ ŞOICA ${ }^{4}$, CORINA DANCIU $^{5}$, IULIANA POPESCU ${ }^{6}$, ILEANA COCAN $^{7 *}$, DACIAN LALESCU $^{7}$, \\ DANINA MIRELA MUNTEAN ${ }^{8}$
}

\author{
${ }^{I}$ Department of Physical Chemistry, Faculty of Pharmacy, "Victor Babeş" University of Medicine and Pharmacy, 2 Eftimie \\ Murgu Square, 300041, Timişoara, Romania \\ ${ }^{2}$ Department of Food Control, Faculty of Agro-food Technologies, "Regele Mihai I al României" Banat's University of \\ Agricultural Sciences and Veterinary Medicine, 119 Calea Aradului Street, 300641, Timişoara, Romania \\ ${ }^{3}$ Department of Toxicology, Faculty of Pharmacy, "Victor Babeş" University of Medicine and Pharmacy, 2 Eftimie Murgu \\ Square, 300041, Timişoara, Romania \\ ${ }^{4}$ Department of Pharmaceutical Chemistry, Faculty of Pharmacy, "Victor Babeş" University of Medicine and Pharmacy, 2 \\ Eftimie Murgu Square, 300041, Timişoara, Romania \\ ${ }^{5}$ Department of Pharmacognosy, Faculty of Pharmacy, "Victor Babeş" University of Medicine and Pharmacy, 2 Eftimie \\ Murgu Square, 30004, Timişoara, Romania \\ ${ }^{6}$ Department of Soil Science, Faculty of Agriculture, "Regele Mihai I al României” Banat's University of Agricultural \\ Sciences and Veterinary Medicine, 119 Calea Aradului Street, 300641, Timişoara, Romania \\ ${ }^{7}$ Department of Food Technologies, Faculty of Agro-food Technologies, "Regele Mihai I al României” Banat's University of \\ Agricultural Sciences and Veterinary Medicine, 119 Calea Aradului Street, 300641, Timişoara, Romania \\ ${ }^{8}$ Department of Pathophysiology - Functional Sciences, Faculty of Medicine, "Victor Babeş" University of Medicine and \\ Pharmacy, 2 Eftimie Murgu Square, 300041, Timişoara, Romania
}

*corresponding author: negreaileana@yahoo.com

Manuscript received: June 2018

\begin{abstract}
Propolis is a natural resinous mixture produced by honeybees in order to strengthen, isolate and sanitize the hive that has been systematically reported to exert a plethora of beneficial effects on human health. The aim of the present study was to analyse the lipid profile of 8 propolis samples collected from producers in Western Romania. Lipids were extracted with a Soxtest system and analysed by gas chromatography-mass spectrometry (GC-MS). The total lipid level showed an average value of $33.17 \pm 0.16 \%(\mathrm{w} / \mathrm{w})$. A total number of 56 lipids were identified, among which $\sim 30 \%$ were fatty acids, ranging from $24.50 \%$ to $45.13 \%$ in lipids extracted; unsaturated fatty acids were reported between $4.22 \%$ and $13.40 \%$ in samples. In particular, 8 fatty acids were identified as being present in all the investigated propolis samples: palmitic, oleic, behenic, arachidic, stearic, $\alpha$-linolenic (essential fatty acid from $\omega-3$ series), myristic and lauric acid. Principal components analysis and cluster analysis were performed to analyse the data.
\end{abstract}

\section{Rezumat}

Propolisul reprezintă un amestec de substanţe răşinoase fiind produs de către albine pentru întărirea, izolarea şi dezinfectarea stupului, recunoscut a avea numeroase acţiuni benefice asupra sănătăţii umane. Scopul acestui studiu a constat în caracterizarea profilului lipidic a 8 eşantioane de propolis obținute de la producători din vestul României. Lipidele au fost extrase utilizând un sistem Soxtest şi ulterior analizate prin gaz-cromatografie cuplată cu spectrometrie de masă (GC-MS). Conţinutul total de lipide a fost în medie $33.17 \%(\mathrm{~m} / \mathrm{m})$. S-au identificat 56 de lipide, dintre care $\sim 30 \%$ au fost acizi graşi, aceştia regăsindu-se în probe între $25.40 \%$ şi $45.13 \%$, în timp ce concentraţia de acizi graşi nesaturaţi în probe a variat de la $4.22 \%$ la $13.40 \%$. În principal, 8 acizi graşi au fost caracteristici tuturor probelor analizate, şi anume: palmitic, oleic, behenic, arahidic, stearic, $\alpha$-linolenic (acid gras esenţial din seria $\omega-3$ ), miristic şi lauric. Datele au fost prelucrate statistic prin analiză chemometrică (analiză în componente principale și analiză cluster).

Keywords: propolis, fatty acids, lipid compounds, GC-MS, PCA, cluster analysis

\section{Introduction}

Propolis has been largely used as a dietary supplement for its large spectrum of beneficial effects on human health. The chemical composition of propolis is extremely complex and highly variable [15], its major constituents $(50 \%)$ being resins (flavonoids, phenolic acids) and bee-wax (30\%, waxes and fatty acids). Other components are essential and aromatic oils, pollen, organic and mineral substances, vitamins and sugars [6]. Propolis contains more than 300 compounds from different chemical classes [16], the major biologically active substances belonging to phenolic 
FARMACIA, 2019, Vol. 67, 1

acids and flavonoids classes; the same holds true for the composition of the Romanian propolis [11]. Regarding the lipids, they are often left aside as it is considered that they are limiting the polyphenol content, thereby reducing the biological activity of propolis. It is considered that propolis of good quality contains a low concentration of wax, Stan et al. proposing a maximum value of $40 \%$ to differentiate between adulterated and unadulterated form [15]. The variations in the chemical composition of propolis are due to the variability of vegetation available to bees, region of production, illumination, altitude, season characteristics, bee species, the technique used for collection etc. [16]. Also, when a hive tool was used for sampling, the propolis samples were reported to have a higher wax concentration [11]. At variance, when the samples were collected by a propolis collector, the amount of wax was less than $21 \%$ [15]. The percentage of lipids in propolis is relatively high, Romanian propolis containing around $35 \pm 8 \%$ wax [15].

Long-chain polyunsaturated fatty acids (PUFAs) are essential fatty acids with 18 - 20 carbons or more that exert a crucial role in human health since they are involved in cholesterol metabolism, neurotransmission, blood coagulation and the immune response [1]. As components of membrane phospholipids, fatty acids influence the properties of cellular membranes, such as fluidity and permeability. $\omega-3$ and $\omega-6$ PUFAs also modulate the inflammatory response and exhibit antioxidant, neuroprotective and cardio-protective properties [13]. $\omega-3$ PUFAs have beneficial effects in reversing the inflammation of adipose tissue and insulin resistance in obesity as well as in enhancing insulin secretion in type II diabetes patients [3]. The monounsaturated oleic acid ( $\omega-9)$ possesses antitumour effects in different cancer types (e.g. tongue squamous cell carcinomas [10], breast cancer [4]) and Ehrlich ascites tumour - in the latter case it was less effective as compared to palmitoleic acid [9].

The aim of the present study was to assess the lipid composition, in particular the fatty acids content in propolis samples harvested from 8 sites located in Western Romania.

\section{Materials and Methods}

\section{Propolis Samples}

Eight propolis samples (abbreviated P1 - P8) were harvested from producers in the Western Romania between 2015 and 2016. Table I presents the characteristics of the samples. An aliquot for each propolis sample was used for lipid analysis.

\begin{tabular}{|c|c|c|c|c|c|c|c|c|}
\hline Sample & P1 & $\mathbf{P 2}$ & P3 & $\mathbf{P 4}$ & P5 & P6 & P7 & P8 \\
\hline $\begin{array}{c}\text { Location } \\
\text { type }\end{array}$ & $\begin{array}{c}\text { meadow/ } \\
\text { forest }\end{array}$ & forest & meadow & meadow & $\begin{array}{c}\text { meadow/ } \\
\text { forest }\end{array}$ & meadow & $\begin{array}{c}\text { meadow/ } \\
\text { forest }\end{array}$ & forest \\
\hline $\begin{array}{l}\text { Harvesting } \\
\text { year/time }\end{array}$ & $\begin{array}{l}2015, \\
\text { Spring } \\
\text { (May) }\end{array}$ & $\begin{array}{l}2015, \\
\text { Spring } \\
\text { (April) } \\
\end{array}$ & $\begin{array}{c}2015, \\
\text { Autumn }\end{array}$ & $\begin{array}{c}2015, \\
\text { all harvest } \\
\text { period }\end{array}$ & $\begin{array}{c}2015, \\
\text { Autumn }\end{array}$ & $\begin{array}{c}2015, \\
\text { Summer } \\
\text { (June/July) }\end{array}$ & $\begin{array}{c}2016, \\
\text { Autumn } \\
\text { (September) } \\
\end{array}$ & $\begin{array}{c}2016, \\
\text { Summer } \\
\text { (July) }\end{array}$ \\
\hline $\begin{array}{l}\text { Collection } \\
\text { method }\end{array}$ & $\begin{array}{c}\text { By hive } \\
\text { tools }\end{array}$ & $\begin{array}{c}\text { By hive } \\
\text { tools }\end{array}$ & $\begin{array}{c}\text { By means of a } \\
\text { propolis } \\
\text { collector }\end{array}$ & $\begin{array}{l}\text { By hive } \\
\text { tools }\end{array}$ & $\mathrm{N} / \mathrm{A}$ & $\begin{array}{c}\text { By hive } \\
\text { tools }\end{array}$ & $\begin{array}{c}\text { By hive } \\
\text { tools }\end{array}$ & $\begin{array}{c}\text { By hive } \\
\text { tools }\end{array}$ \\
\hline $\begin{array}{c}\text { Apiary } \\
\text { type }\end{array}$ & \multicolumn{4}{|c|}{ stationary } & $\begin{array}{l}\text { stationary and } \\
\text { migratory }\end{array}$ & \multicolumn{3}{|c|}{ stationary } \\
\hline $\begin{array}{l}\text { Physical } \\
\text { aspect }\end{array}$ & & & & & & & & \\
\hline
\end{tabular}

\section{Total Lipid Determination}

Lipids were extracted from propolis in petroleum ether using a Soxtest Raypa SX-6 MP equipment. Three $\mathrm{g}$ of pulverized propolis was introduced into the cartridges. For the extraction of lipids, $50 \mathrm{~mL}$ petroleum ether was used for each sample. Parameters were set as follows: temperature: 75 , time of extraction: 50 minutes. Samples were dried to constant weight. Total fat was expressed as percentage from raw propolis $(\% \mathrm{w} / \mathrm{w})$.

Fatty Acids Methyl Esthers (FAMEs) Profile Assessment The fatty acids from total lipids extracted from propolis were analysed as fatty acid methyl esthers (FAMEs) after derivatization of fatty acids contained in $0.1 \mathrm{~g}$ lipids with $3 \mathrm{~mL}$ boron trifluoride methanol solution $20 \%$. Derivatization was performed for 1 hour at 80 in an ultrasonic bath. After cooling, $2.5 \mathrm{~mL} \mathrm{NaCl}$ solution $10 \%$ was added and FAMEs were extracted in $2 \mathrm{~mL}$ hexane. The organic layer was separated by centrifugation at $3000 \mathrm{rpm}$ for 15 minutes. FAMEs were analysed using a ShimadzuGCMS-QP2010PLUS equipment and aAT-WAX column $(30 \mathrm{~m}, 0.32 \mathrm{~mm}$ i.d., $1 \mu \mathrm{m}$ thickness). The temperature program was isotherm initially at $140^{\circ} \mathrm{C}$ for $10 \mathrm{~min}$ and then increasing the temperature with $7^{\circ} \mathrm{C} / \mathrm{min}$ up to $250^{\circ} \mathrm{C}$ and maintaining at this temperature for $10 \mathrm{~min}$. (total 
FARMACIA, 2019, Vol. 67, 1

run: $35.71 \mathrm{~min}$.). Split ratio was 1:10 and injection port temperature was set at $250^{\circ} \mathrm{C}$. The ion source and interface temperatures were $210^{\circ} \mathrm{C}$ and $255^{\circ} \mathrm{C}$ using a Shimadzu GCMS-QP2010 PLUS equipment and a AT-WAX column $(30 \mathrm{~m}, 0.32 \mathrm{~mm}$ i.d., $1 \mu \mathrm{m}$ thickness). Hexane was used as solvent for FAMEs and helium as carrier gas at a flow rate of $1.00 \mathrm{~mL} / \mathrm{min}$ and a linear velocity of $37.8 \mathrm{~cm} / \mathrm{sec}$. FAMEs peaks were identified using NIST05 library and quantified by area normalization method. The percentage of various lipid compounds in propolis was determined by reporting the peak area corresponding to a specific compound to the total peak area (for all identified constituents) of chromatograms.

\section{Statistical Analysis}

Data are presented as means \pm standard deviation and were analysed using one-way ANOVA or student ttest when appropriate $\left(\right.$ Microsoff ${ }^{\circledR}$ Excel, 2010). Values of $\mathrm{p}<0.05$ were considered statistically significant. Principal component analysis (PCA) was applied to the values of the FAMEs and Ward's clustering method was performed using the Euclidean distance, according to Statistica 10.0 (StatSoft Inc., Tulsa, USA).

\section{Results and Discussion}

\section{Total Lipid Content}

The lipid content of the analysed propolis samples was between $20.21 \%$ and $37.73 \%$ (mean value of $33.17 \pm 5.16 \%$ ). Figure 1 presents the lipid percentages in all samples; as depicted, the lowest amount of lipids was found in sample P3 harvested from Şiria (Arad county, Romania), by means of a propolis collector. Using the same method, Hindi et al. determined a comparable percentage of fat $-20 \%$ in propolis samples collected from Iraq [7]. Interestingly, it has been reported that Malaysian propolis (Southeast Asia) produced by stingless bees Heterotrigona itama contains $21.43 \pm 5.39 \%$ total fat, whereas the one produced by Geniotrigona thoracica contained $73.47 \pm 2.75 \%$ fat $[8]$.

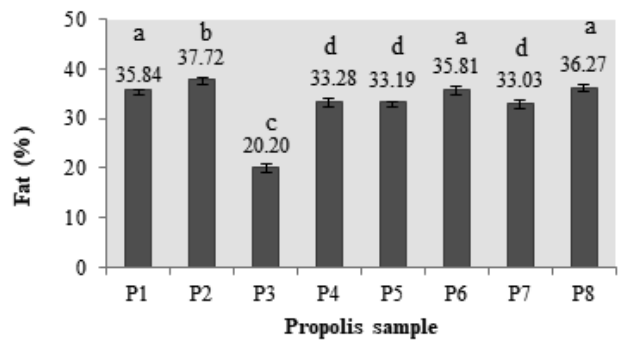

Figure 1.

Total lipid determination in raw propolis (Soxhlet extraction)

Distinct letters indicate significant difference according to t-test

\section{Lipid Profile Analysis}

The GC-MS analysis of propolis indicated a complex mixture of components belonging to several classes: fatty acids, alkanes, sesquiterpenoids, bicyclic sesquiterpenes, ethers (crown ethers, epoxides), mixed esters, aromatic compounds, halogenated compounds, alkenes, fatty alcohols, organosilicon compounds (siloxanes). The compounds belonging to the fatty acids class were predominant $(30.36 \%$ of the total number of identified compounds), followed by alkanes (14.29\%) and sesquiterpenoids (12.5\%).

A total number of 17 fatty acids was identified in propolis lipid fraction, in various percentages ranging from $0.02 \%$ to $9.30 \%$ (average value), most of them being saturated acids (12 acids; $71 \%$ of total number of fatty acids), 3 monounsaturated $(\omega-7, \omega-9)$ and 2 PUFAs $(\omega-2, \omega-3)$, including the essential fatty acid $\alpha$-linolenic. The 17 fatty acids identified in the analysed samples are presented in Table II.

Presentation of the 17 fatty acids identified as FAMEs in propolis

\begin{tabular}{|c|c|c|c|}
\hline \multicolumn{4}{|c|}{ SATURATED FATTY ACIDS } \\
\hline Lipid abbreviation & $\% *$ & Fatty acid type & Fatty acid common name \\
\hline C12:0 & 0.65 & Dodecanoic acid & Lauric acid \\
\hline C14:0 & 0.71 & Tetradecanoic acid & Myristic acid \\
\hline C16:0 & 7.77 & Hexadecanoic acid & Palmitic acid \\
\hline $\mathrm{C} 17: 0$ & 0.33 & Hexadecanoic acid, 14-methyl & 14-Methylpalmitic acid \\
\hline C18:0 & 2.17 & Octadecanoic acid & Stearic acid \\
\hline C19:0 & 0.05 & Octadecanoic acid, -17-methyl & - \\
\hline $\mathrm{CPA}^{* *}$ & 0.02 & Cyclopropanepentanoic acid, 2-undecyl & - \\
\hline C20:0 & 2.20 & Eicosanoic acid & Arachidic acid \\
\hline $\mathrm{C} 21: 0$ & 0.66 & Heneicosanoic acid & Heneicosylic acid \\
\hline C22:0 & 3.31 & Docosanoic acid & Behenic acid \\
\hline $\mathrm{C} 24: 0$ & 9.30 & Tetracosanoic acid & Lignoceric acid \\
\hline $\mathrm{C} 26: 0$ & 2.85 & Hexacosanoic acid & Cerotic acid \\
\hline \multicolumn{4}{|c|}{$\begin{array}{l}\text { MONOUNSATURATED FATTY ACIDS } \\
\end{array}$} \\
\hline Lipid abbreviation & $\% *$ & Fatty acid type & Fatty acid common name \\
\hline $\mathrm{C} 16: 1, \omega-7$ & 0.78 & 9-Hexadecenoic acid $(\mathrm{Z})$ & Palmitelaidic acid; cis-Palmitoleic acid \\
\hline $\mathrm{C} 16: 1, \omega-9 / \mathrm{C} 16: 1, n-9$ & 0.13 & 7-Hexadecenoic acid $(\mathrm{Z})$ & Hypogeic acid \\
\hline C18:1, $\omega-9$ & 6.23 & 9-Octadecenoic acid (Z) & Oleic acid \\
\hline
\end{tabular}


FARMACIA, 2019, Vol. 67, 1

\begin{tabular}{|c|c|c|c|}
\hline \multicolumn{4}{|c|}{ POLYUNSATURATED FATTY ACIDS } \\
\hline Lipid abbreviation & $\% *$ & \begin{tabular}{|c|} 
Fatty acid type \\
\end{tabular} & Fatty acid common name \\
\hline $\mathrm{C} 18: 2, \omega-2$ & 0.26 & 13,16-Octadecadienoic acid & - \\
\hline$C 18: 3, \omega-3$ & 1.16 & 9,12,15-Octadecatrienoic acid** & a-Linolenic acid $* * *$ \\
\hline
\end{tabular}

*peak area percent of the total peak area from GC-MS analysis; **CPA = cyclopropane fatty acid class; ***Essential fatty acid; Note: The 8 compounds written in bold and italic have been found in all samples.

The following 8 lipids belonging to the fatty acids class have been found in all the analysed samples: C16:0, C18:1, C22:0, C20:0, C18:0, C18:3, C14:0, $\mathrm{C} 12: 0$; thus we can assume that these fatty acids are characteristic for the collected propolis. Among lipid compounds, three were the dominant ones: C24:0 with the average percentage in analysed hexane fraction of $9.30 \%$ (from $0 \%$ (in P1, P2, P6) to $22.66 \%$ (in P4)), C16:0 - average value $7.77 \%$ (from $2.62 \%$ in $P 8$ to $18.71 \%$ in P1) and C18:1 - average value $6.23 \%$ (from $5.7 \%$ in $\mathrm{P} 2$ to $11.25 \%$ in $\mathrm{P} 1$ ).
C18:3 was found in every sample, ranging from $0.36 \%$ (P3) to $2.07 \%(\mathrm{P} 2)$, with an average value of $1.16 \%$ for the 8 analysed samples. Algerian propolis was found to contain a reduced percent of this acid (from $0.05 \%$ to $2.12 \%$; average value: $0.40 \%$ ), but the presence of linoleic acid was also reported (average value in the 8 samples: $5.12 \%$ ) [14].

In Table III the proportion of different types of fatty acids is summarized.

Concentration of fatty acid groups identified as FAMEs in analysed propolis samples

\begin{tabular}{|l|c|c|c|c|c|c|c|c|c|}
\hline \multicolumn{1}{|c|}{ Fatty acid group } & P1 & $\mathbf{P 2}$ & $\mathbf{P 3}$ & $\mathbf{P 4}$ & $\mathbf{P 5}$ & $\mathbf{P 6}$ & $\mathbf{P 7}$ & P8 & $\begin{array}{c}\text { Mean } \\
\text { P1 } \rightarrow \text { P8 }\end{array}$ \\
\hline Saturated & 28.48 & 13.78 & 25.10 & 39.05 & 25.48 & 22.49 & 33.40 & 39.09 & 28.36 \\
\hline Unsaturated & 13.40 & 10.72 & 12.20 & 4.22 & 5.05 & 7.24 & 6.42 & 6.04 & 8.16 \\
\hline Unsaturated/saturated ratio & 0.47 & 0.78 & 0.49 & 0.11 & 0.20 & 0.32 & 0.19 & 0.15 & 0.34 \\
\hline Monounsaturated & 12.38 & 8.65 & 9.23 & 3.86 & 4.45 & 5.42 & 5.82 & 4.09 & 6.74 \\
\hline Polyunsaturated & 1.03 & 2.07 & 2.97 & 0.36 & 0.60 & 1.82 & 0.60 & 1.95 & 1.43 \\
\hline Polyunsaturated/Monounsaturated & 0.08 & 0.24 & 0.32 & 0.09 & 0.13 & 0.34 & 0.10 & 0.48 & 0.22 \\
\hline$\omega-3$ & 1.03 & 2.07 & 0.86 & 0.36 & 0.60 & 1.82 & 0.60 & 1.95 & 1.16 \\
\hline$\omega-9$ & 12.28 & 5.70 & 9.23 & 3.86 & 4.45 & 5.42 & 5.82 & 4.09 & 6.36 \\
\hline Hypercholesterolaemic $(\mathrm{C} 14: 0+\mathrm{C} 16: 0)$ & 19.51 & 4.31 & 10.97 & 8.43 & 5.17 & 4.55 & 12.10 & 2.77 & 8.48 \\
\hline $\begin{array}{l}\text { Hypocholesterolaemic }(C 18: 1+C 18: 2+C 18: 3+ \\
\text { C20:3 + C20:4 + C20:5 + C22:4+ C22:5+C22:6) }\end{array}$ & 12.28 & 7.77 & 12.20 & 4.22 & 5.05 & 7.24 & 6.42 & 6.04 & 7.65 \\
\hline Hypo-/hyper-cholesterolaemic ratio & 0.63 & 1.80 & 1.11 & 0.50 & 0.98 & 1.59 & 0.53 & 2.18 & 1.17 \\
\hline Total fatty acids & 41.88 & 24.50 & 37.30 & 43.27 & 30.53 & 29.73 & 39.82 & 45.13 & 36.52 \\
\hline
\end{tabular}

Note: values in the table represent percent of the total area from GC-MS analysis.

As showed in Table III, the percentage of total fatty acids in our samples varied from $24.50 \%$ to $45.13 \%$ (mean value $36.52 \%$ ). Our results are similar with percentages reported by Rebiai et al. for the Algerian propolis $(21.21 \%-55.6 \%$; mean $38 \%)$. At variance, in Yemen propolis (Western Asia) a lower concentration of fatty acids $(0.25 \%-0.78 \%$, mean $7.22 \%)$ was found [2].

In Algerian propolis the saturated fatty acids represented $41 \%$ whereas in Romanian propolis they represented up to $71 \%$. Also, 16 unsaturated fatty acids were determined ( 7 monosaturated, 9 polyunsaturated) in the Algerian propolis, among which 10 were found in all samples (pamitoleic, oleic, elaidic, linoleic, $\gamma$-linolenic, $\alpha$-linolenic, cis-11,14-eicosadienoic, cis-11,14,17-eicosatrienoic, heneicosylic, cis-5,8,11, 14,17-eicosapentanoic and cis-13,16-docosadienoic acid). Interestingly, Romanian Western propolis contained 5 unsaturated fatty acids ( 3 monounsaturated, 2 polyunsaturated), 2 of (oleic and $\alpha$-linolenic acid) them being present in all samples. Unsaturated fatty acids in Romanian propolis ranged between $4.22 \%$ and $13.40 \%$ (mean value: $8.16 \%$ ), whereas in Algerian propolis their percentage varied between $19.72 \%$ and $51.85 \%$ (mean value: $35.58 \%$ ). The percentage of $\omega-3$ fatty acids in Romanian propolis (interval of variation: $0.36 \%-3.07 \%$; mean value: $1.16 \%$ ) was higher as compared to that in Algerian propolis $(0.05 \%-2.17 \%$, mean value: $0.57 \%)$, but $\omega-6$ fatty acids were reported only in Algerian propolis and in high concentrations (from $5.74 \%$ to $33.43 \%$, mean: 22\%) [14]. Thus, one can state that Algerian propolis contains more numerous and varied monoand unsaturated fatty acids $(\omega-3, \omega-6, \omega-9)$ than Romanian propolis.

From the alkanes class, only heneicosane was present in all the analysed samples, ranging from $0.84 \%$ (in P8) to $13.13 \%$ (in P5) - average percentage in samples: $3.97 \%$. Within this class, the highest mean percentages have been noticed for the following three compounds: tetracosane (from $0 \%$ (in P6) to $19.49 \%$ (in P1); average: $7.16 \%$ ), tetracontane (from $0 \%$ (in P2, P5, P6) to $13.95 \%(\mathrm{P} 1)$; average: $6.69 \%)$ and pentacosane 
(from $0 \%(\mathrm{P} 1, \mathrm{P} 5)$ to $10.12 \%(\mathrm{P} 2, \mathrm{P} 4)$; average: $5.21 \%)$.

The percentage of sesquiterpenoids was reduced in all the samples, the maximum value being observed in P1 sample for clovene (3a,7-Methano-3aH-cyclopentacyclooctene) $-0.37 \%$. This sesquiterpenoid prevailed in samples ( 5 samples out of 8 contained clovene; $0 \%$ in $\mathrm{P} 2, \mathrm{P} 5 \mathrm{P} 8 ; 0.37 \%$ in $\mathrm{P} 1$; average: $0.17 \%$ ). In sample P2 a variety of sesquiterpenoids/ sesquiterpenes has been determined, but in rather low concentrations: $\beta$-cadinene $(0.11 \%), \alpha$-eudesmol $(0.10 \%), \beta$-guaiene, juniperol (longiborneol), $\alpha$ amorphene, calamenene.

The number of identified lipids/sample varied from 25 (in P5 sample) to 40 (in P2 sample). In Figure 2 the main lipids present in an average concentration above $1 \%$ in our samples are displayed.

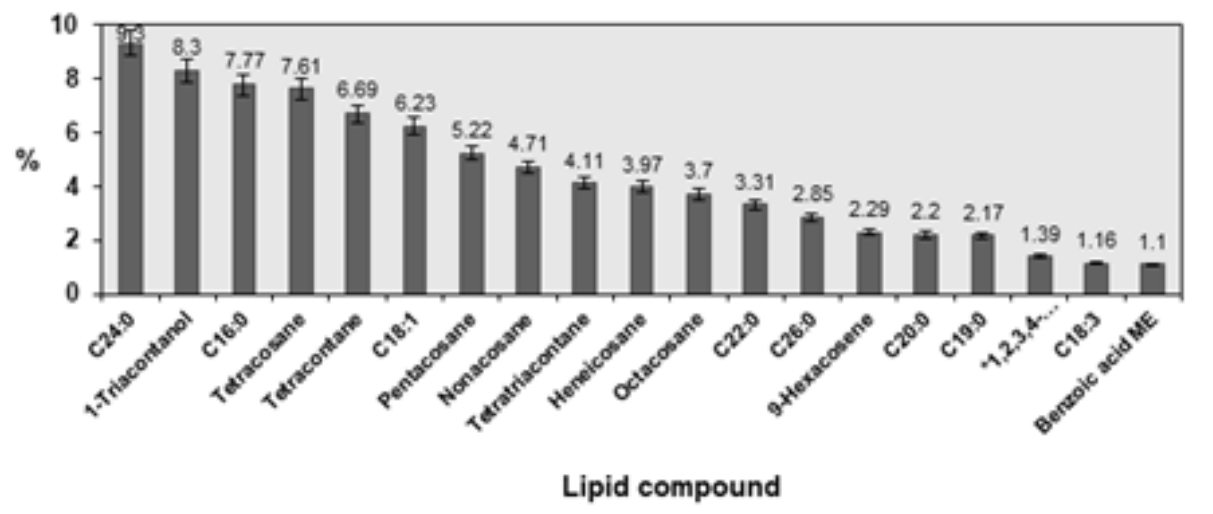

Figure 2.

Major lipids identified in propolis hexane fraction through GC-MS analysis *1,2,3,4-Tetrahydronaphtalene-1-carboxylic acid

C24:0 was determined in propolis hexane fraction, ranging from $0 \%(\mathrm{P} 1, \mathrm{P} 2, \mathrm{P} 6)$ to $22.66 \%(\mathrm{P} 4)$, with an average value (for the 8 samples) of $9.30 \%$. 1 Triacontanol was identified in concentrations from $0 \%$ (P1, P4, P8) to $25.68 \%$ (P5), average value: $8.30 \%$.
C14:0 was found in all the 8 samples ranging between $2.62 \%(\mathrm{P} 8)$ and $18.71 \%(\mathrm{P} 1)$, average value: $7.77 \%$.

All samples contained the following lipids: C16:0, C18:1, heneicosane, C20:0, C22:0, C18:0, C18:3, $\mathrm{C} 14: 0$ and $\mathrm{C} 12: 0$ (Figure 3).

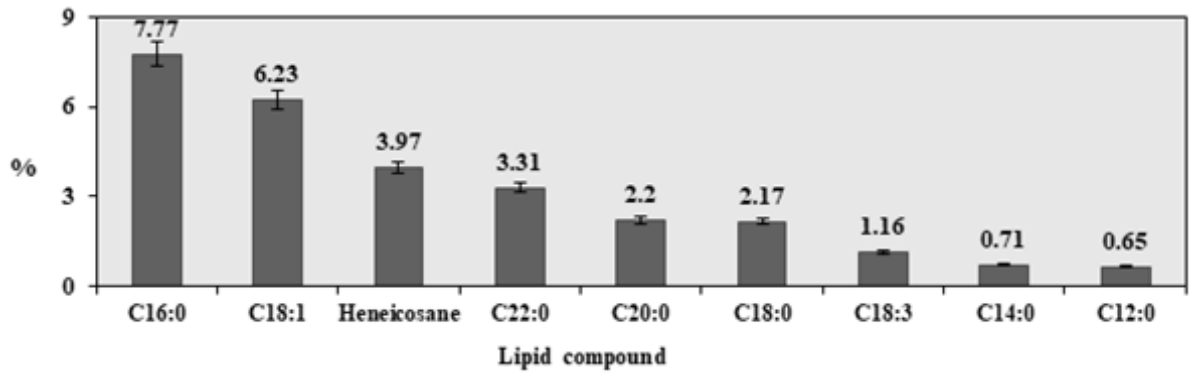

Figure 3.

The characteristic lipids for the propolis samples

As shown in Figure 3, the first three lipids present in higher concentrations are as follows: C16:0 was found in propolis hexane fraction ranging from $2.62 \%$ (P8) to $18.71 \%(\mathrm{P} 1)$ - average value for the 8 samples: $7.77 \%$; $C 18: 1$ was determined in concentrations varying from $3.86 \%(\mathrm{P} 4)$ to $11.25 \%(\mathrm{P} 1)$ - average value: $6.23 \%$, while heneicosane was reported in concentrations between $0.84 \%$ (P8) and 13.13\% (P5) - average value: $3.97 \%$ (Figure 4). 


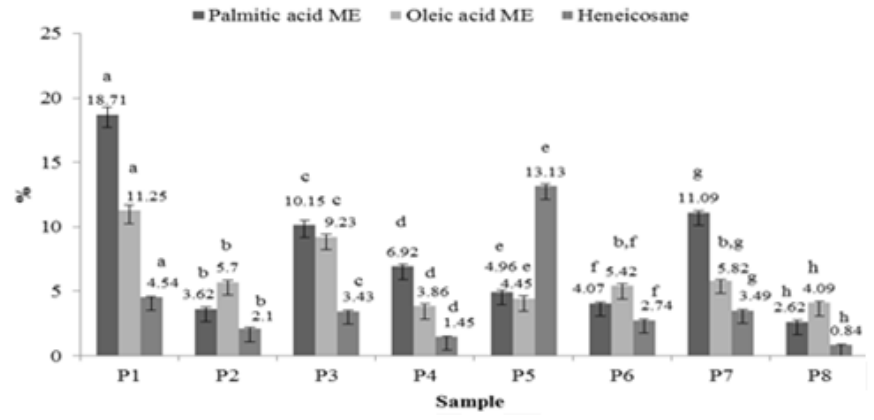

Figure 4.

The distribution of main specific lipids in the 8 propolis samples

Besides their well-known anti-inflammatory and antiatherosclerotic properties (reviewed recently by Denisow) [5], fatty acids play important roles in the crosstalk with several other active molecules e.g., the reactive oxygen species [12]; the latter is a research direction that clearly warrants further investigation.

Principal components analysis (PCA) and cluster analysis

The multi-parametric statistical analysis methods, principal component analysis and cluster analysis, were used for further analysis of the data. Based on the matrix of linear correlations, a PCA was applied to the values of the measured parameters in order to assess their contribution to total data variation. The PCA resulted in 7 components, with the first two principal components accounting for $36.76 \%$ and $24.01 \%$ of variance (a total of $60.77 \%$ ). The most important variables integrated in the first component were $\mathrm{C} 20: 0$ and $\mathrm{C} 26: 0$ which were positively correlated with this component, while C16:0, C18:1, C19:0, C22:0, C21:0, C14:0, C12:0, C16:1, $\omega-9$, C18:2 were negatively correlated with this first component. The second component was positively correlated with CPA, C24:0 and negatively correlated with C18:3, C18:0, C17:0, C16:1, $\omega-7$ (Figure 5).

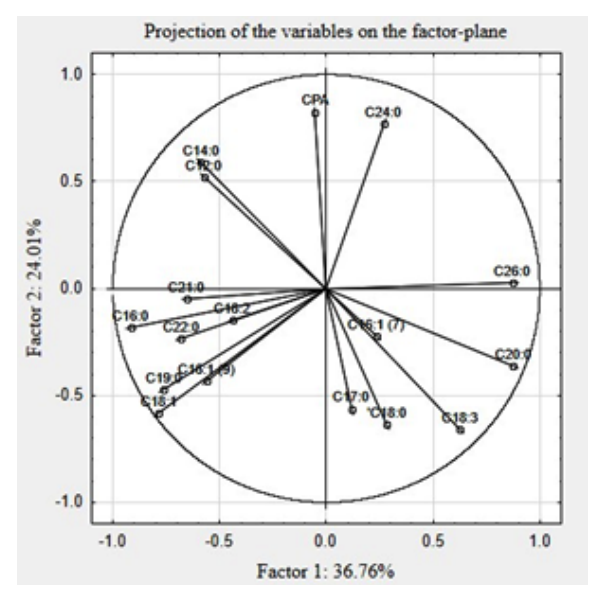

Figure 5.

Projection of the variables on the plane

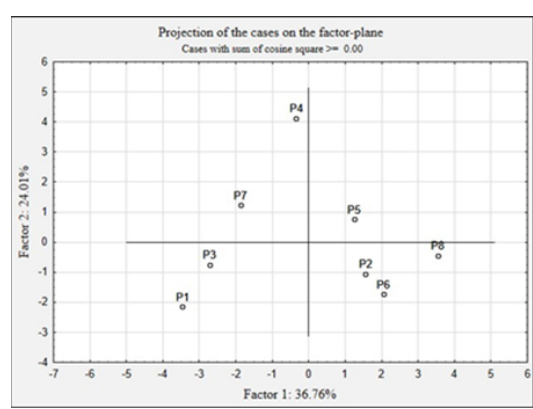

Figure 6.

Projection of the cases on the plane spanned by the first and second principal components

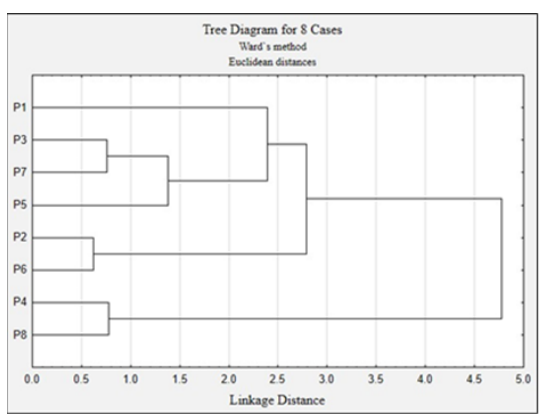

Figure 7.

Cluster dendrogram of samples 
The similarity among fatty acids was examined when each sample was plotted using the first and second principal components (Figure 6).

Using cluster analysis, a dendrogram which divided individual propolis into clusters was drawn. Clusters classified individual propolis into 3 groups based on similar characteristics: Group 1 - P1, P3, P7, P5; Group 2 - P2 and P6; Group 3 - P4 and P8 (Figure 7).

\section{Conclusions}

Propolis represents a natural resinous product rich in lipids (mean: $33.17 \% \mathrm{w} / \mathrm{w}$, in raw propolis). Various lipid compounds were reported in propolis: fatty acids (saturated, mono- and polyunsaturated), alkanes (heneicosane especially), sesquiterpenoids (mainly clovene) and others. Eight fatty acids were identified in all analysed samples: palmitic, oleic, behenic, arachidic, stearic, $\alpha$-linolenic, myristic and lauric acid. Using cluster analysis, we were able to suggest a dendrogram which divides individual bee propolis into three representative clusters based on mutual similarity of the measured parameters.

\section{Acknowledgement}

The chemical research was performed in the Interdisciplinary Research Platform belonging to "Regele Mihai I al României” Banat's University of Agricultural Sciences and Veterinary Medicine from Timişoara, Romania.

\section{References}

1. Abedi E, Sahari MA, Long-chain polyunsaturated fatty acid sources and evaluation of their nutritional and functional properties. Food Sci Nutrit., 2014; 2: 443-463.

2. Al-Ghamdi A, Bayaqoob NIM, Rushdi AI, Alattal Y, Simoneit BRT, El-Mubarak AH, Al-Mutlaq KF, Chemical compositions and characteristics of organic compounds in propolis from Yemen. Saudi J Biol Sci., 2017; 24: 1094-1103.

3. Baynes HW, Mideksa S, Sintayehu A, The role of polyunsaturated fatty acids (n-3 PUFAs) on the pancreatic $\beta$-cells and insulin action. Adipocyte, 2018; 0: $1-7$.
4. Carillo C, Cavia M del M, Alonso-Torre SR, Antitumor effect of oleic acid; mechanisms of action. A review. Nutr Hosp., 2012; 27: 1860-1865.

5. Denisow B, Denisow-Pietrzyk M, Biological and therapeutic properties of bee pollen: A review. $J$ Sci Food Agric., 2016; 6(13): 4303-4309.

6. Farooqui T, Farooqui AA, Beneficial effects of propolis on human health and neurological diseases. Frontiers Biosci., 2012; 4: 779-793.

7. Hindi NKK, Al-Charrakh AH, Naher HS, Abbas AS, Study of chemical analysis of Iraqi propolis and active component of propolis. Iraq J Sci., 2015; 5: 1095-1103.

8. Ibrahim N, Niza NFSM, Rodi MMM, Zakaria AJ, Ismail Z, Mohd KS, Chemical and biological analyses of Malaysian stingless bee propolis extracts. Malaysian J Analyt Sci., 2016; 20: 413-422.

9. Ito H, Kasama K, Naruse S, Shimura K, Antitumor effect of palmitoleic acid on Ehrlich ascites tumor. Cancer Letters, 1982; 17: 197-203.

10. Jiang L, Wang W, He Q, Wu Y, Lu Z, Sun J, Liu Z, Shao $Y$, Oleic acid induces apoptosis and autophagy in the treatment of tongue squamous cell carcinomas. Sci Rep (Springer Nature), 2017; 7: 11277: 1-11.

11. Mărghitaș LA, Dezmirean DS, Bobiș O, Important developments in Romanian propolis research. Evid Based Complement Alternat Med., 2013; 2013: 159392: 1-9.

12. Mihai CM, Mărghitaș LA, Dezmirean DS, Bărnuțiu L, Correlation between polyphenolic profile and antioxidant activity of propolis from Transylvania. Anim Sci Biotech., 2011; 44(2): 100-103.

13. Nagy K, Tiuca ID, Importance of Fatty Acids in Physiopathology of Human Body. Chap. 1 in Biochemistry, Genetics and Molecular Biology, "Fatty Acids", edited by InTech Prof. Angel Catala. 2017; 3.

14. Rebiai A, Belfar ML, Mesbahi MA, Nani S, Tliba A, Amara GD, Chouikh A, Fatty acid composition of Algerian propolis. J Fund App Sci., 2017; 9: 1656-1671.

15. Stan L, Mărghitaș LA, Dezmirean D. Quality criteria for propolis standardization. Anim Sci Biotech., 2011; 44: 137-140.

16. Toreti VC, Sato HH, Pastore GM, Park YK, Recent progress of propolis for its biological and chemical compositions and its botanical origin. Evid Based Complement Alternat Med., 2013; 2013: 697390: 1-13. 